\title{
Managing corporate identities of non-profit organisations in the social welfare sector
}

\begin{tabular}{|c|c|}
\hline \multicolumn{2}{|c|}{$\begin{array}{l}\text { Author: } \\
\text { Lida Holtzhausen }{ }^{1}\end{array}$} \\
\hline \multicolumn{2}{|c|}{$\begin{array}{l}\text { Affiliation: } \\
\text { School of Communication } \\
\text { Studies, North-West } \\
\text { University, South Africa }\end{array}$} \\
\hline \multicolumn{2}{|c|}{$\begin{array}{l}\text { Correspondence to: } \\
\text { Lida Holtzhausen }\end{array}$} \\
\hline \multicolumn{2}{|c|}{$\begin{array}{l}\text { Email: } \\
\text { lida.holtzhausen@nwu.ac.za }\end{array}$} \\
\hline \multicolumn{2}{|c|}{$\begin{array}{l}\text { Postal address: } \\
\text { Private Bag X6001, } \\
\text { Potchefstroom 2520, } \\
\text { South Africa }\end{array}$} \\
\hline \multicolumn{2}{|c|}{$\begin{array}{l}\text { Dates: } \\
\text { Received: } 14 \text { Aug. } 2012 \\
\text { Accepted: } 26 \text { Feb. } 2013 \\
\text { Published: } 11 \text { Mar. } 2013\end{array}$} \\
\hline \multicolumn{2}{|c|}{$\begin{array}{l}\text { How to cite this article: } \\
\text { Holtzhausen, L., 2013, } \\
\text { 'Managing corporate } \\
\text { identities of non-profit } \\
\text { organisations in the social } \\
\text { welfare sector', Jàmbá: } \\
\text { Journal of Disaster Risk } \\
\text { Studies 5(2), Art. \#88, } \\
8 \text { pages. http://dx.doi. } \\
\text { org/10.4102/jamba.v5i2.88 }\end{array}$} \\
\hline \multicolumn{2}{|c|}{$\begin{array}{l}\text { 1st Biennial Conference, } \\
\text { Southern African Society for } \\
\text { Disaster Reduction (SASDiR), } \\
09 \text { to } 11 \text { October 2012, } \\
\text { Potchefstroom, South Africa. }\end{array}$} \\
\hline \multicolumn{2}{|c|}{$\begin{array}{l}\text { Copyright: } \\
\text { (C) 2013. The Authors. } \\
\text { Licensee: AOSIS } \\
\text { OpenJournals. This w } \\
\text { is licensed under the } \\
\text { Creative Commons } \\
\text { Attribution License. }\end{array}$} \\
\hline \multicolumn{2}{|l|}{ Read online: } \\
\hline 口ifida & $\begin{array}{l}\text { Scan this QR } \\
\text { code with your } \\
\text { smart phone or } \\
\text { mobile device } \\
\text { to read online. }\end{array}$ \\
\hline
\end{tabular}

Present-day South Africa is characterised by many societal and developmental issues, such as HIV awareness and prevention, child-headed households, environmental protection, poverty alleviation, violence and victim aid. However, it is widely acknowledged that government alone cannot address these issues effectively. The role of non-profit organisations (NPOs) in addressing social and development issues is increasingly emphasised. NPOs work at grassroots level and they can therefore, on the whole, identify societal vulnerabilities and risks earlier than the government sector. However, due to the economic recession, NPOs operate in a competitive environment where an increasing number of NPOs rely on a small number of donors and other resources. NPOs should therefore differentiate themselves from the competition in order to obtain public legitimacy and funding. Corporate identity management is important for NPOs to fulfil their role in social welfare and thus contribute to disaster risk reduction. The exploratory nature of this study dictates a qualitative research approach. Semi-structured interviews with management of five NPOs in the social welfare sector were conducted in order to provide an answer to the study's research question: 'To what extent do NPOs in the social welfare sector practise corporate identity management, in order to prevent and address social welfare risks?' The research found that NPOs do not realise the full potential of managing their corporate identities. NPOs therefore do not take advantage of a strong and distinct corporate identity which would allow them to ensure their ability to assess, address, reduce and/or alleviate vulnerabilities and disaster risks.

\section{Introduction}

\section{Background of the study}

South Africa has made remarkable progress in consolidating the country's transition to democracy, but millions of South Africans, both urban and rural, are still confronted with having to survive unemployment, homelessness, lack of basic services, HIV, food insecurity and unacceptable levels of crime and violence. Confronted by the complexity of these development challenges, possibly one of the biggest failures is a lack of communication between the various sectors and stakeholders ${ }^{1}$ in development (Degenaar 2012 [Public Relations Officer, NG Welfare, pers. comm.]; Mbuli 2008; Miller 2012 [Chief Executive Officer, Project Literacy, pers. comm.]).

In this context of developmental challenges non-profit organisations (NPOs) inherently work toward vulnerability reduction through social welfare, thus providing a voice to the poor, creating platforms for relationships characterised by mutual trust, and positioning themselves as organisations aimed at changing the face of South Africa's developmental state.

However, due to an increasing growth in the number of NPOs in South Africa these organisations operate in a highly competitive environment where everyone is largely dependent on donors ${ }^{2}$ for financial support. It is becoming increasingly expensive and difficult to gain funds (Cutlip et al. 2002:304; Fussell, Sisco, Collins \& Zoch 2009; Wilcox \& Cameron 2006). Although obtaining donations is not the only criterion for success in the NPO sector, the importance of donors and donations in the non-profit sector is inimitable. NPOs, to a greater extent than for-profit organisations, depend on a positive corporate image in order to collect and/or gain funding, since they do not offer a product to sell, but rely on people's goodwill and positive perceptions of the organisation (Dyer et al. 2002:13-17; Sargeant 2001). Furthermore, NPOs need to inform and educate potential donors about real needs and problems within the communities they serve (Wiggill et al. 2009), many of which could have a profound impact on the level of disaster risk. Within the framework of this research disaster risk reduction (DRR) is defined as:

1.A stakeholder is any individual or group of individuals who are affected by the decisions, activities and achievements of the organisation and who, in turn, might affect the organisation (Holtzhausen 2008).

2.NPOs can receive donations from donors without having to return the funds or in some cases donors can expect NPOs to deliver services or reports to their beneficiaries (Skinner, Von Essen \& Mersham 2004; Wilcox \& Cameron 2006; Wiggill, Naude \& Fourie 2009). 
the systematic development and application of policies, strategies and practices to minimise vulnerabilities and disaster risk throughout a society, to avoid (prevent) or to limit (mitigate and prepare) adverse impacts of hazards, within the broader context of sustainable development (International Strategy for Disaster Reductions [ISDR] 2002:25; Van der Waldt 2009; Van Riet 2009)

Applying this definition to the NPO sector in South Africa indicates that NPOs are faced with the struggle to deal with the consequences of government's failure to address many social welfare issues, as well as the challenge to differentiate themselves and stand out from the masses in order to have a competitive advantage (Judd 2001:6; Swilling \& Russell 2002). Relationships with donors, in particular, have to be built for the sustainable survival of the organisations, thereby enabling DRR activities. A method that NPOs can use to differentiate themselves is to maintain and manage their corporate identity (Belasen 2008:127; Van Dyk 2007:6).

If the NPOs succeed in managing their corporate identities effectively, it may serve as the foundation for developing and maintaining positive relationships with their respective donors as well as a means to position themselves strategically within the communities that they serve. Although some NPOs recognise that their relationships with donors is of great importance for their survival, various forms of communication, such as corporate identity management, take place without the necessary planning and without clear objectives for the development of these relationships (Cornelissen 2012; Dyer et al. 2002:15). NPOs need a positive image and reputation due to financial implications where they do not have sufficient funds to support or market themselves effectively. A good relationship with donors is essential, since they have the power to positively or negatively influence the organisation's goal attainment (Holtzhausen 2008) and to contribute to multi-stakeholder DRR. Against this background NPOs should be able to create and establish relationships with various stakeholders, particularly donors, by means of managing their corporate identities, thus creating a tool that can enable them to position themselves as organisations that are able to address, alleviate and influence positively the many societal problems which are characteristic to South Africa.

\section{Research objective}

Against this background this study aims to address the following research objective: to determine to what extent NPOs in the social welfare sector practise corporate identity management, in order to prevent and alleviate social welfare risks.

\section{Key focus on the study}

In order to address the above-mentioned research objective, the theoretical framework underlining the study should be examined, namely corporate identity management.

\section{Corporate identity: Defining the term}

Within the literature there are several views that give insights about the terms 'corporate identity' and 'corporate identity management'. Some academics are of the opinion that the term 'identity' has expanded to the point where it forms the basis for concepts such as image, reputation and trademarks (Van Riel 1995). Young (2001) argues that corporate identity refers to what is central, distinctive and enduring about the organisation. Others, such as Van Riel and Balmer (1997) and Cornelissen and Elving (2003), argue that identity is manifested in the values, beliefs, behaviour, communication and symbols that are unique to the organisation. It furthermore refers to the basic profile that an organisation wants to project to all of its stakeholders and how the organisation is seen in terms of the image and reputation of the organisation (Cornelissen 2008:11). For the purpose of this study, corporate identity can be defined as:

... the planned presentation of an organisation. It is created, amongst others, from the foundation laid by the vision and mission of the organisation, organisational strategies, daily operations, products (where applicable) and services, personnel policies, structure, culture to marketing. (Cornelissen \& Elving 2003; Ingenhoff \& Fuhrer 2010; Melewar \& Wooldridge 2001; Otubanjo, Amujo \& Cornelius 2010; Van Riel 1995; Van Riel \& Balmer 1997)

\section{Corporate identity: Elements}

Based on the above-mentioned definition, there are three main components that need to be kept in mind when managing corporate identity (Bick, Abratt \& Bergman 2008; Cornelissen \& Elving 2003; Otubanjo \& Melewar 2007; Van den Bosch, De Jong \& Elving 2004; Van Riel 1995; Van Riel \& Balmer 1997). Symbolism is one of the most important components from an identity management viewpoint, as this is the component the organisation has the most control over. It is the starting point for developing an identity as it reflects the essence of the organisation. Symbolism consists of visual and non-visual elements. Visual identity elements aim to make the organisation recognisable in order to distinguish it from other organisations. Typical visual identity elements include: the organisation's name; logo; colours; signs and billboards, et cetera. Non-visual identity elements are not concrete or tangible, but often represent themselves in the visible elements of the identity (Allessandri 2001). These can include, amongst others, organisational values, organisational objectives and organisational structure.

These elements are conveyed to stakeholders by means of communication and behaviour. Communication includes all intentional messages sent by the organisation to different stakeholders, including donors (Körver \& Van Ruler 2003; Stuart \& Kerr 1999; Van Riel 1995).

Identity is furthermore shaped by the organisation's behaviour (Körver \& Van Ruler 2003; Melewar \& Storrie 2001; Van Rekom 1997; Van Riel 1995). Just as individuals are judged by their actions, organisations can be judged by 
the manner in which they behave (operate). Organisational behaviour could include the interactions amongst employees of the NPO (internally) as well as all interactions between the NPO as organisation and its different external stakeholders such as donors. Company behaviour is difficult to manage and often manifests itself in non-visual cues.

Corporate identity thus consists of several elements, which may include, amongst others, the body's logo, colours, names, communication elements, vision, mission, values, history, culture, nature and more. The focus of this paper is specifically on the way literature indicates corporate identity should be managed in order to serve as a means to establish relationships with the stakeholders, particularly donors, and ultimately, position the NPO as an organisation able to assess possible risk-related societal and developmental issues in the social welfare sector.

\section{Corporate identity: Management}

The management of an organisation's identity is of strategic value and requires a multidisciplinary approach (Van Riel \& Balmer 1997:341). According to literature the purpose of managing an identity is to create a favourable reputation amongst the organisation's stakeholders that may create a preference regarding their decision to support the specific organisation through buying its products and making use of its services, to work for the organisation, and to invest in the organisation or donate funds as in the case of NPOs (Van Riel \& Balmer 1997:341-342).

Identity management can be defined as the strategic development of a specific and coherent image of an organisation that is constantly communicated to stakeholders' (Cornelissen \& Elving 2003:116). This implies that the organisation has a management philosophy that is embedded in the mission and vision of the organisation. The values associated with this philosophy need to be communicated from the management to employees and external stakeholders (Melewar, Karaosmanoglu \& Paterson 2005:61). Effective identity management requires that the organisation apply certain principles. For the purposes of this paper and considering the nature of the organisations that took part in the research the following aspects seem to be most applicable: visibility, consistency, authenticity, distinctiveness, transparency, credibility and increased interaction with stakeholders (Abratt 1989; Belasen 2008; Boyd 2003; Fombrun \& Van Riel 2004; Melewar \& Saunders 1998; Quirke \& Lamb 1999; Van den Bosch et al. 2005, 2006; Van Riel \& Balmer 1997):

- Visibility: refers to the organisation's exposure. Stakeholders need to be able to see what the organisation is trying to project.

- Consistency: means that the elements of the identity are applied as was intended. Everything the organisation does should underline the identity of the organisation. The identity should be so clear-cut that it becomes a measurement tool for all other activities. Being consistent allows the organisation to be unified, especially in its behaviour.

- Authenticity: will entail that the organisation goes back to its origin, history and traditions and then uses that as a means to develop a genuine, powerful and trustworthy identity that stands the test of time. It almost provides the organisation with a 'being grounded feeling'.

- Distinctiveness: refers to the unique position of the organisation in the minds of stakeholders. Being distinctive means emphasising something unique about the organisation and steering it away from the competition and into a specific place within the stakeholders' frame of mind.

- Transparency: means the organisation does what it says it will do; almost 'what you see is what you get'. Stakeholders can trust the organisation, knowing that the organisation is real, with nothing to hide.

- Credibility: A credible organisation is seen as sincere, genuine, accurate and reliable. The organisation must be clear about who and/or what it is. There must be consensus on this within the organisation. The organisation must articulate its identity and remain true to that identity.

- Increased interaction with stakeholders: refers to increasing contact (conversations) with the organisation's internal and external stakeholders. In the case of NPOs, this could refer to regular conversations between the organisations and their respective donors.

It is clear that NPOs should manage their corporate identity as a whole by focusing on all of the above-mentioned aspects, but this is no easy task.

\section{The non-profit sector}

Non-profit organisations in South Africa are 'vulnerable and susceptible to the winds of change which blow from all sides' (Miller 2012 [pers. comm.]). These organisations function in a context characterised by hopelessness, poverty, crime, ill-health and multiple disaster risk stressors (Eloff 2012 [Director, Potchefstroom Service Centre for the Aged, pers. comm.]; Herman 2012 [Deputy General Secretary, Solidarity, pers. comm.]; Miller 2012 [pers. comm.]; Van Riet \& Van Niekerk 2012). Non-profit organisations experience tremendous frustrations due to the lack of resources and finances. The fact that the need in our society is far greater than can be imagined, and that the time is too limited to give sufficient attention to specific persons in need, even further increases the feeling of being overwhelmed (Degenaar 2012 [pers. comm.]).

Within this context NPOs play an important role in contributing to DRR in South Africa by examining the nature of communities' vulnerability and, on the basis of that analysis, incorporating appropriate measures (Benson, Twigg \& Myers 2001; Holloway 2003; Van Riet 2012). Nonprofit organisations should be able to articulate a clear actual or perceived threat, identify a victim and expose a possible source. This will fire public interest, give rise to lobbying and ultimately to regulations can be introduced in order to address this issue (Tench \& Yeomans 2006). 
From a corporate identity management perspective these organisations need to stay true to the mission and vision of the organisation, providing quality in the work they do and represent. They should be more responsive and transparent with a commitment to work at increasing the impact made by NPOs (Miller 2012 [pers. comm.]). According to Tench and Yeomans (2006), the information send out by NPOs should be beyond reproach in order for them to retain their reputation and credibility and to gain mutual understanding between the organisation and its many stakeholders. This emphasises the importance of dialogue between all parties involved.

The NPOs that formed part of this research included five organisations from the social welfare sector in South Africa:

- NG Welfare: is a charity that portrays something of God's love to people in need. The branches all over South Africa are involved in different communities through several actions and projects. Their focus of community work is on poverty, HIV and drug abuse, as well as on the protection of vulnerable children, child neglect and abuse, women and the elderly, regardless of race, creed or gender. The activities are aimed at developing independence amongst the people and empowering them in order to enable them to help themselves. NG Welfare is a registered Welfare Organisation (Art. 13, Law 110 of 1978) as well as a Non Profit Organisation (NPO Act 71 of 1997). Their mission is being committed to a comprehensive professional welfare service. Their vision is optimal functioning of the individual, family, and community to God and their credo is faith, hope and love in action. Typically within the context of DRR this would imply that the organisation is constantly challenged to effectively link people experiencing social problems with resources in the community in which it functions. If indeed these resources do not exist, it would imply that NG Welfare would develop these resources where needed (Degenaar 2012 [pers. comm.]).

- FAMSA: The Family and Marriage Society of South Africa (FAMSA) is the national leader in services that enhance relationships. They strive to support individuals, families, organisations, communities and society in building, restoring and sustaining functional relationships. From a DRR perspective they believe that healthy and stable relationships promote healthy individuals, families and communities. The family is the nucleus of society, and when it weakens or crumbles the stability of the entire community is affected dramatically. It is thus imperative to initiate and coordinate resources in order to maintain a healthy and happy marriage and family life. FAMSA was established as a result of this need, according to M. Oelofse, Director of FAMSA, Potchefstroom, in a conversation with the author in 2012.

- Project Literacy: This organisation was established in 1973 to address the needs of illiterate and semi-literate adults in South Africa and has more than 30 years of experience in ABET (Adult Basic Education Training) provision. The link between DRR and education is well known and ample research exists in this regard (UNICEF 2012). It is a well- established and respected non-governmental organisation (NGO). This organisation reaches adult learners nationwide through offices in the different provinces. Project Literacy is involved in the development and provision of a wide range of successful Education and Training programmes for learners and educators from ABET level 1 through to NQF 6. They develop materials for large civic education campaigns such as the Independent Electoral Commission and the European Union Commission for Human Rights. Learning material also includes ABET levels 1-4 for the current General Education and Training Certificate (GETC) as well as training material for clients who require customised interventions. They work in partnership with government departments, corporate clients, other NGOs, community organisations and educational bodies. Project Literacy writes relevant, accessible materials for adults and its success in linking educator training and learner materials programmes has been used by both government and the private sector (Miller 2012 [pers. comm.]).

- Potchefstroom Service Centre for the Aged: The Potchefstroom Service Centre for the Aged was established in October 1983. The aim of this centre is to provide services that would enable the elderly to function independently in the community for as long as possible. The success of the centre lies in the active involvement of its members and the community (Eloff 2012 [pers. comm.]). Primary services include social work services such as preparation for retirement; social, emotional, psychological and spiritual needs for members; nursing services; transport; domestic and gardening services; and meals. Secondary services include hairdressing, tours and excursions, indoor and outdoor activities, as well as club meetings.

- Solidarity: Solidarity believes that institutions should be created through which its members and their communities may live and prosper. Solidarity functions in the Christian tradition of trade unionism, and its unique approach to trade unionism differs therefore from that of COSATU (one of the other major unions in South Africa). Solidarity Movement includes the following institutions: the Solidarity union; civil rights organisation AfriForum; service organisation Helping Hand; technical training centre Sol-Tech; telematic higher education institution Academia; Solidarity Financial Services; Empowerment Fund Solidarity Growth Fund; Solidarity Investment Company; Solidarity Property Company; the Campus; the new internet-driven-media house Marula Media; Kraal Publishers; and the Solidarity Research Institute (Herman 2012 [pers. comm.]). In contributing to DRR in South Africa, Solidarity's main task is to ensure job security, to improve employment conditions and to eliminate injustice in the workplace.

\section{Research methodology Research approach and method}

A qualitative research approach was applied with the use of semi-structured interviews. Semi-structured interviews 
include a standard set of questions that define the line of thought, with one or more questions tailored to clarify certain aspects of the respondents' responses as well as probing the respondents' reasoning (Leedy \& Ormrod 2010:188; Wagnet, Kawulich \& Garner 2012:133). The five interviews were conducted with management from the NPOs concerned with numerous responsibilities such as the administration of the organisations, communication and day-to-day activities, to name but a few. The majority of the organisations do not have an individual who is responsible solely for the communication function. It is usually the directors, social workers, and others with the responsibility to perform these functions that do so above and beyond their normal daily operations.

\section{Data collection method}

Before the interviews could be conducted, legitimacy had to be established. The researcher explained that she was from the North-West University and had undertaken a research project aimed at identity management in the non-profit sector. The interviewer also emphasised the importance of the research during each of the interviews. During the interviews it was possible to establish a form of rapport with the interviewees, which had a positive effect on the interview situations. Here reference was made to telephonic as well as electronic correspondence that explained the importance of the project to the respondents. It had already laid some foundation before the researcher and the respondents came into face-to-face contact with one another.

\section{Ethical considerations during the semi- structured interviews}

During a semi-structured interview the respondents are not absolutely anonymous (Babbie 2004:66; Hocking, Stacks \& McDermott 2003:247) and so, during this study, it was important to provide a guarantee that the identity of the respondents, their names and other details would be kept strictly confidential. Their responses were thus grouped together and no personal reference was made to any of their comments in the discussion of the results. The interviews were recorded with the permission of the interviewees as well as transcribed for future reference.

\section{Data analysis}

The results were analysed according to the theoretical guidelines set out in the literature study and are qualitatively discussed. The aim of this paper and of the exploratory research conducted at this stage is not to compare the operations of the different NPOs but to create an understanding of the essence of what corporate identity management entails within the context of these NPOs as well as how these organisations can utilise their identities in order to create a powerful platform from which dialogue can stem forth so that these NPOs can conduct their daily operations, contribute to DRR and build relationships with important stakeholders within the challenging social welfare sphere of South Africa in order to support the masses who would otherwise be vulnerable and often desperate. This study is a work in progress and much work still needs to be done. The current aim is to lay a foundation and work from there.

\section{Limitations of the research}

From an academic viewpoint the management of corporate identity within the context of NPOs was addressed, but the study did not focus on the application of the organisations' different identities within the unique social context wherein they operate. Furthermore, the nature of the organisations differed significantly (despite all operating in the social welfare sector) which could contribute to an unfair playing field with regard to how corporate identity management could be structured. Although organisational behaviour and communication, as elements of identity management, were addressed during the interviews, these elements could be elaborated on in more detail. This will necessitate an in-depth study on the theory of strategic communication management and whether this theoretical viewpoint is in any way relevant to this very unique context. This paper did not incorporate a developmental communication framework, which would contribute significantly to the body of knowledge surrounding this topic. From a research perspective, this study can also be repeated at other NPOs in South Africa, especially NPOs from different sectors which would provide a new-found basis for the management of corporate identities and their influence on stakeholder relationships. Also, additional interviews could be conducted, not only with the management of the different NPOs, but more specifically those involved in daily operations so as to provide further insight into how the NPOs structure and manage their identities with regard to their donors and other stakeholders, keeping in mind their responsibility with regard to DRR.

\section{Findings and discussion}

In general it seems that there is willingness in all five of the organisations who took part in this research project, and planning processes are in place, to address and prevent the major societal problems with which they are confronted. People in need turn increasingly to NPOs whilst many of these organisations struggle to make ends meet with the state that threatens their subsidy or even worse, withdraws funding completely. For these NPOs, obtaining operating funds is a necessity that dominates much of their efforts. Without generous contributions from companies and individuals whose money is hard earned these organisations can find it difficult to exist. Funders (such as companies and other stakeholders) also have different expectations and these expectations are increasing because people at all levels of society are experiencing financial difficulties (Eloff 2012 [pers. comm.]; Herman 2012 [pers. comm.]; Miller 2012 [pers. comm.]). Within this context, NPOs' communication functions focus on those who have an interest in the organisations and in that regard identity management is very important for these organisations' wide range of stakeholders and services. 
Although there is some level of identity management found in the five organisations who took part in the research project, there is still much room for refinement and a more integrated approach. These organisations do not always have the funds to appoint communication practitioners to manage this function in order to perform, so it does not receive the necessary attention and is not always the priority it should be. The communication function, with specific reference to identity management, is often the responsibility of one of the employees, for example, a social worker with little or no knowledge of communication. With the exception of Solidarity and NG Welfare, the organisations did not have a communication practitioner who could take responsibility for the management of the NPO's identity. Identity management is used to build relationships with various interest groups by keeping them constantly informed about the organisations and their various functions. Factors such as lack of funds and personnel, and different target markets (homes for the aged, welfare offices, child and youth care centres and community work), tend to complicate these efforts.

Furthermore, the interviewees' responses indicated that in many ways they try to communicate their identity to their stakeholders in a visual manner. It is interesting to note that most organisations tend to focus on the logo and regard it as the largest and most important visual means. One of the interviewees mentioned that: '... We are visible through our logo. The logo makes us a corporate organisation and not just another welfare organisation'. It seems that the organisations realise there is some consistency in the application of the organisation's identity, although the majority indicated that variation is allowed and in some cases they do not really know how to stop or prevent this, as is evident from the following responses: 'We try to keep the colours the same - we have a specific pantone for our logo, but I often come across many variations of the colour of official documentation'. In addition, it appears that some of the NPOs allow variation because they feel pressure when they try to be consistent as some sections of the organisation are hostile to the parent organisation. So they allow a certain level of chaos, as long as the primary functions of these sections are performed, as is evident from the following response: 'As long as it looks neat and professional we do not care'.

The majority of respondents indicated that the authenticity of the identity is of utmost importance and the focus of who they are and what they are trying to achieve. Almost all of the organisations stated that they are proud of their history, about what they have accomplished over time and that they strive to reach their future goals. Examples of such responses are: 'We are proud of our heritage. We've come very far and that is our strength', 'Our organisation has stood the test of time. We communicate that to our employees as well as our external stakeholders' and 'We know what we stand for and how we can make a difference'. Each of the organisations was aware of what their unique identity entails and the way in which they can address the needs of society. Some respondents stated that their organisations do not have a manual on how their identity must be used and communicated, but they still try to apply transparency. The organisations indicated that they are 'honest', 'open' and 'trustworthy' in terms of what they do. Each organisation indicated that they need to communicate the organisation's functions to their stakeholders, such as donors, if they wish to receive funding. NPOs should not, as respondents put it, 'hide' what they do with the funds, because transparency serves as a means to gain trust and to build a relationship with the stakeholders. They all indicated that they needed to explain what they currently were busy with. Several of the organisations indicated that the expression of the organisation's values is part of the credibility of the organisation. One such a response illustrates this by saying: 'It manifests itself in the services we provide'. During the interviews it was clear that the NPOs value the aspect requiring them to be faithful to who and what they are. The respondents indicated that the staff must be committed to their task, because it reflects outwards. They especially emphasised passion for what they accomplished and truly make a difference in the context within which they function.

The respondents indicated different responses with regard to how their identity is transferred and/or communicated to all its stakeholders. However, it appears that most of the organisations communicate both internally and externally with their stakeholders. Unfortunately, it is also true that some recognise the value of communication with their stakeholders and use certain methods to communicate with them, but some admit that what they currently do is insufficient as is evident from the following response:

I realise that our organisation needs to continuously communicate with our donors and I wish they could have a look at each project, but when I think how long it takes, I'd rather focus on the important tasks to be performed. There is just too much to do and too little time for everything.

\section{Conclusions and recommendations}

It is not possible to generalise with regard to the greater non-profit sector, but from the research done it seems that efforts are made to manage identities in the different NPOs who took part in the research, but, as was evident from the interviews, it is no easy task and success is not easily defined within this context. There is much room for further development and identity management, as a means to assist NPOs in their responsibility regarding DRR has not yet reached its full potential in this sector. In some cases, only the logo is cited as being the most important aspect of their identity as it is the way in which the organisation is differentiated or distinguished from other organisations. These NPOs do not (in most cases) have the necessary funds to appoint communication practitioners to manage this function in order to perform optimally, so it does not receive the necessary attention and is not a primary priority. The communication function, with specific reference to identity management, is often just relegated to one of the employees, for example, a social worker, with little or no knowledge of communication. 
Furthermore, South Africa is in the midst of great societal uncertainties. The aim of NPOs should be to protect their stakeholders (especially those who are in desperate need of the services rendered by the NPOs), deliver better services and, although not operating for the purpose of making a profit, manage themselves so that they do generate profit which will enable them to support themselves, especially when funding is becoming a somewhat rare phenomenon. Although non-profits find themselves in difficult financial times they need to renovate and almost reinvent themselves, in order to be capable of fully addressing the many social problems in SA, and to indicate to those who support them (especially financially) that they are to be trusted, that they are committed to making a difference, that they deliver on their promises, and to ensure open communication channels with all their stakeholders. NPOs need to manage their reputations which are built on their identities because it is the organisation's reputation that often creates a lifeline in uncertain times. Through identity management, efforts should be made to communicate the organisation's true values and philosophy to all stakeholders in order to generate a sense of ownership amongst these stakeholders, creating a platform for trust and ultimately relationship building which can assist NPOs in their drive to reduce the many societal problems in SA.

\section{Suggestions for future research}

Future research will include more NPOs, to draw a comparison between the different sectors in which these organisations function and ultimately to develop a model showing how corporate identity within this context can be managed given the problems and characteristics of this sector.

\section{Acknowledgments Competing interests}

The author declares that she has no financial or personal relationship(s) which may have inappropriately influenced her in writing this paper.

\section{References}

Abratt, R., 1989, 'A new approach to the corporate image management process', Journal of Marketing Management 5(1), 63-76. http://dx.doi.org/10.1080/0267 257X.1989.9964088

Alessandri, S.W., 2001, 'Modelling corporate identity: a concept explication and theoretical explanation', Corporate Communications: an International Journal 6(4), 173-182. http://dx.doi.org/10.1108/EUM0000000006146

Babbie, E., 2004, The practice of social research, 10th edn., Wadsworth, Belmont, CA.

Bick, G., Abratt, A.R., Bergman, A., 2008, 'Perceptions of the corporate identity management process in South Africa', South African Journal of Business Management 39(3), 11-20.

Belasen, A.T., 2008, The theory and practice of corporate communication: a competing values perspective, SAGE Publications, Los Angeles.

Benson, C., Twigg, J. \& Myers, M., 2001, 'NGO initiatives in risk reduction: An overview', Disasters 25(3), 199-215. http://dx.doi.org/10.1111/1467-7717.00172

Boyd, J., 2003, 'A quest for synergy: the war metaphor and the construction of identity', Communication studies 54(3), Autumn, 249-264.

Cornelissen, J., 2008, Corporate communications: a guide to theory and practice, 2nd edn., Sage, London. http://dx.doi.org/10.1108/1356328031047553

Cornelissen, J., 2012, Corporate communications: a guide to theory and practice, 3rd edn., Sage, London.
Cornelissen, J.P. \& Elving, W.J.L., 2003, 'Managing corporate identity; an integrative framework of dimensions and determinants', Corporate Communication: an International Journal 8(2), 116.

Cutlip, S.M., Center, A.H., Broom, G.H. \& du Plessis, D.F., 2002, Essentials of effective public relations for Sub-Saharan Africa, Maskew Miller Longman, Cape Town.

Dyer, S., Buell, T., Harrison, M. \& Webber, S., 2002, 'Managing public relations in nonprofit organisations', Public Relations Quarterly 47(4), Winter, 13-17.

Fombrun, C.J. \& Van Riel, C.B.M., 2004, Fame and fortune: how successful companies build winning reputations, Prentice Hall, Upper Saddle River, N.J.

Fussell Sisco, H., Collins, E.L. \& Zoch, L.M., 2009, 'Through the looking glass: a decade of Red Cross crisis response and situational crisis communication theory', Public Relations Review 36(2010), 21-27. http://dx.doi.org/10.1016/j. pubrev.2009.08.018

Hocking, J.E., Stacks, D.W. \& McDermott, S.T., 2003, Communication research, 3rd edn., Allyn \& Bacon, Boston, MA.

Holloway, A., 2003, 'Disaster risk reduction in Southern Africa', African Security Review 12(1), 29-38. http://dx.doi.org/10.1080/10246029.2003.9627568

Holtzhausen, L., 2008, 'Employee perceptions of symbolic corporate identity elements and employer-employee relationships at Lonmin Platinum', doctoral thesis, Faculty of Arts, NWU, Potchefstroom.

Ingenhoff, D. \& Fuhrer, T., 2010, 'Positioning and differentiation by using brand personality attributes. Do mission and vision statements contribute to building unique corporate identity?', Corporate Communications: an International Journa 15(1), 83-101. http://dx.doi.org/10.1108/13563281011016859

International Strategy for Disaster Reductions (ISDR), 2002, Living with risk: A global review of disaster reductions initiatives, preliminary version, ISDR Secretariat, Geneva.

Judd, V.C., 2001, 'Toward a customer-orientation and a differentiated position in a nonprofit organization: Using the 5th P-people', Journal of Nonprofit \& Public Sector Marketing 9(1-2), 5-17. http://dx.doi.org/10.1300/J054v09n01_02

Körver, F. \& Van Ruler, B., 2003, 'The relationship between corporate identity structures and communication structures', Journal of Communication Management $7(3)$ 197-208. http://dx.doi.org/10.1108/13632540310807377

Leedy, P.D \& Ormrod, J.E., 2010, Practical research. Planning and design, Pearson Education International, Boston.

Mbuli, B.N., 2008, 'Poverty reduction strategies in South Africa', Master of Commerce (in the subject Economics) dissertation, UNISA.

Melewar, T.C., Karaosmanoglu, E. \& Paterson, D., 2005, 'Corporate identity: concept, components and contribution', Journal of General Management 13(1), Autumn, 59-81.

Melewar, T.C. \& Saunders, J., 1998, 'Global corporate visual identity systems: standardization, control and benefits', International Marketing Review 15(4), 291-308. http://dx.doi.org/10.1108/02651339810227560

Melewar, T.C. \& Storrie, T., 2001, 'Corporate identity in the service sector', Public Relations Quarterly 46(2), Summer, 20-26.

Melewar, T.C. \& Wooldridge, A.R., 2001, 'The dynamics of corporate identity: a review of a process model', Journal of Communication Management 5(4), 328. http:// dx.doi.org/10.1108/13632540110806866

Otubanjo, B.O. \& Melewar, T.C., 2007, 'Understanding the meaning of corporate identity: a conceptual and semiological approach', Corporate Communications: an International Journal 12(4), 414-432. http://dx.doi org/10.1108/13563280710832542

Otubanjo, O., Amujo, O.C. \& Cornelius, N., 2010, 'The informal corporate identity communication process', Corporate Reputation Review 13(3), 157-171. http:// dx.doi.org/10.1057/crr.2010.18

Quirke, B. \& Lamb, A., 1999, 'Get your internal communication match fit', Strategic Communication Management 3(4), June/July, 24-29.

Sargeant, A., 2001, 'Relationship fundraising: how to keep donors loyal', Nonprofit Management and Leadership, 12(2), Winter 177-192. http://dx.doi.org/10.1002/ nml.12204

Skinner, C., Von Essen, L. \& Mersham, G., 2004, Handbook of public relations, 7th edn., Oxford Southern Africa, Cape Town.

Stuart, H. \& Kerr, G., 1999, 'Marketing communication and corporate identity: are they integrated?', Journal of Marketing Communication 5, 169-179. http://dx.doi. org/10.1080/135272699345572

Swilling, M. \& Russell, B., 2002, The size and scope of the non-profit sector in South Africa, Graduate School of Public and Development Management, University of the Witwatersrand, Johannesburg, South Africa; Centre for Civil Society, University of Natal, Durban, South Africa.

Tench, R. \& Yeomans, L., 2006, Exploring public relations, Prentice Hall Financial Times, Harlow, U.K.

UNICEF, 2012, 'Disaster risk reduction in school curricula: Case studies from thirty countries', UNICEF, Paris, viewed 22 February 2013, from http://books.google. $\mathrm{com} /$ books?id=InMnINaLB8QC\&printsec=frontcover $\& d q=$ disaster+risk+reductio n+education \&hl=\&cd=7\&source=gbs_api

Van den Bosch, A.L.M., De Jong, M.D.T. \& Elving, W.J.L., 2004, 'Managing corporate visual identity: use and effects of organisational measures to support a consistent self-presentation', Public Relations Review 30(2), 225-234. http://dx.doi. org/10.1016/j.pubrev.2003.12.002 
Van den Bosch, A.L.M., De Jong, M.D.T. \& Elving, W.J.L., 2005, 'How corporate visual identity supports reputation', Corporate Communications: an International Iournal 10(2), 108-116. http://dx.doi.org/10.1108/13563280510596925

Van den Bosch, A.L.M., De Jong, M.D.T. \& Elving, W.J.L., 2006, 'Managing corporate visual identity: exploring the differences between manufacturing and service, and profit-making and nonprofit organisations', Journal of Business Communication 43(2), 138-157. http://dx.doi.org/10.1177/0021943605285476

Van der Waldt, G., 2009, 'Public management and disaster risk reduction: potential interdisciplinary contributions', JÁMBÀ: Journal of Disaster Risk Studies 2(1), 14-27.

Van Dyk, L.I., 2007, 'Die ooreenstemming tussen korporatiewe identiteitsbestuur en belangegroepverhoudinge van die ABSA KKNK', M.A., dissertation, Faculty of Arts, NWU, Potchefstroom.

Van Rekom, J., 1997, 'Deriving an operational measure of corporate identity', European Journal of Marketing 31(5/6), 411-412.

Van Riel, C.B.M., 1995, Principles of corporate communication, Prentice Hall, London \& New York.

Van Riel, C.B.M. \& Balmer, J.M.T., 1997, 'Corporate identity: the concept, its measurement and management', European Journal of Marketing 31(5/6), 340355. http://dx.doi.org/10.1108/eb060635
Van Riet, G., 2009, 'Qualitative and quantitative community level approaches: disaster risk assessment in the Fezile Dabi District Municipality', Africanus 39(2), 31-43.

Van Riet, G., 2012, 'Disaster risk assessment in South Africa: Some current challenges', South African Review of Sociology 40(2), 194-208. http://dx.doi.org/10.1080/21 528586.2009.10425108

Van Riet, G. \& Van Niekerk, D., 2012, 'Capacity development for participatory disaster risk assessment', Environmental Hazards 11(3), 213-225. http://dx.doi.org/10.10 80/17477891.2012.688793

Wagnet, C., Kawulich, B. \& Garner, M., 2012, Doing social research. A global context, McGraw-Hill, London.

Wiggill, M.N., Naude, A.M.E. \& Fourie, L.M., 2009, 'Strategic communication management by NPOs in the adult-literacy sector in South Africa', Communicare 28(1), July, 50-67.

Wilcox, D.L. \& Cameron, G.T., 2006, Public Relations: Strategies and Tactics, 8th edn., Pearson Education, Boston.

Young, D.R., 2001, 'Organisational identity in non-profit organisations: strategic and structural implications', Non-profit Management and Leadership 12(2), Winter, 139-157. http://dx.doi.org/10.1002/nml.12202 